\title{
SAN VICENTE, FÉLIX (ED.) (2008): TEXTOS FUNDAMENTALES DE LA LEXICOGRAFÍA ITALOESPAÑOLA (1917-2007), 2 VOLS. MILÁN, ITALIA, POLIMÉTRICA INTERNACIONAL SCIENTIFIC PUBLISHER. 844 PÁGS.
}

\author{
José JoAquín Martínez Egido \\ Universidad de Alicante \\ jj.martinez@ua.es
}

Dentro del marco de la necesidad y de la actualidad que supone el aprendizaje del español en Italia, con la publicación de muchas obras, entre ellas diccionarios, destinadas a tal menester, era necesario que apareciera un trabajo de estudio lexicográfico que intentara clarificar y definir cuál es la verdadera oferta que se va a encontrar el público receptor de estos materiales en las librerías. Es esta motivación la que mueve al coordinador de este libro, Félix San Vicente, para llevar a cabo de forma tan formidable un trabajo tan ambicioso como el que refleja y constata la publicación de este libro, fruto del proyecto nacional italiano coordinado por G. Iamartino «Glossari, dizionari, corpora: lessicologia e lessicografia delle lingue europee».

De esta forma, Textos fundamentales de la lexicografía italoespañola (1917-2007) nace del trabajo de investigación lexicográfica de sus autores al conocer cómo la publicación de diccionarios, además de ser una actividad lingüística al servicio de unos usuarios concretos, es también un producto de negocio; es decir, el ver cómo, desde sus inicios allá por el siglo XVI, se han sumado ediciones de obras léxicográficas bajo la apariencia de nuevas obras cuando, en realidad, han sido muchas veces simples reimpresiones de lo ya editado con la intención de engañar o seducir al comprador.

Si la motivación, que parte de la realidad existente, está constatada, el siguiente paso debía ser la creación de un equipo de investigación que llevara a cabo tan ingente tarea. Se constituyó con más de quince investigadores que se encargarían del estudio de cada una de las obras seleccionadas abarcando prácticamente todo el siglo XX hasta nuestros días, y siguiendo unas mismas líneas de actuación para evitar el trabajo atomizado y conseguir un resultado verdaderamente homogéneo.

De toda la amalgama de diccionarios en el mercado, este libro nos presenta el análisis de los siguientes productos lexicográficos ${ }^{1}$ : El Dizionario moderno italiano-spagnuolo e spagnuolo-italiano (1917-1927) de G. Frisoni - P. Rodríguez Reina (vol.1, págs. 27-78); El Diccionario italiano-español, spagnuolo-italiano (1943) de J. Ortiz de Burgos - E. Flores Acuña (Vol. 1, págs. 79-124); El Nuovo dizionario spagnolo-italiano e italiano-spagnolo (1948-1949) de L. Ambruzzi - F. Bermejo Calleja (Vol. 1, págs. 125-197); El Dizionario

1 Señalamos el título del trabajo, el autor de su estudio y el volumen y las páginas en las que se encuentra. El volumen 1 enmarca todos los diccionarios publicados durante el siglo XX, desde 1917, mientras que el volumen 2 lo hace con los publicados en el siglo XXI. 
fraseologico completo (1950-1957) de S. Carbonell - H. E. Lombardini (Vol.1, págs. 199271); El Diccionario italiano español, español italiano (1957) de E. M. Martínez Amador - M. T. Sanmarco Bande (Vol. 1, págs. 273-311); El Dizionario spagnolo-italiano, italianospagnolo (1990) y otras obras lexicográficas de A. Gallina - C. Calvo Rigual (Vol. 1, págs. 313-337); El Dizionario spagnolo-italiano, italiano-spagnolo (2000) de L. Lavacchi y C. Nicolás - E. Pérez Vázquez (Vol. 2, págs. 381-415); El Diccionario español italiano Everest Cima (2003) - R. Cinotti (Vol. 2, págs. 417-438); El Grande dizionario di spagnolo-italiano, italiano-spagnolo (2004) de L. Tam - E. Liverani (Vol. 2, págs. 439-493); El Dizionario spagnolo-italiano italiano-spagnolo (2005) de L. Knight y M. Clari - G. Mapelli (Vol. 2, págs. 495-523); El Dizionario spagnolo-italiano, italiano-spagnolo (2005) de S. Sañé y G. Schepisi - A. L. de Hériz (Vol. 2, págs. 525-598); El Dizionario spagnolo-italiano, italianospagnolo (2005) de Espasa-Paravia - C. Bareggi (Vol. 2, págs. 599-631); El Diccionario italiano-spagnolo, español-italiano Herder (2006) de A.Giordano y C. Calvo - R. Cinotti (Vol. 2, págs. 633-665); Los diccionarios Garzanti Spagnolo italiano Piccolo (2002) y Medio (2007) - P. Capanaga (Vol. 2, págs. 667- 715); Los diccionarios bilingües italiano-español del equipo Edigeo para Zanichelli (1989-2007) - V. Nanetti (Vol. 2, págs. 717- 771).

En todos estos trabajos, además de las cuestiones específicas que cada diccionario pudiera ofrecer, se respetan unos puntos comunes de análisis; a saber, el contexto editorial, las fuentes y sus derivados, los destinatarios y las finalidades de las obras, los aspectos formales y textuales, el aparato crítico, la macroestructura, la microestructura, con el estudio de los americanismos, los neologismos, las unidades pluriverbales y los ejemplos y las citas, y el diccionario en CD analogías y variantes. Por ello, esta obra, presenta una doble lectura para el especialista; por un lado una lectura vertical, en la que cada capítulo es independiente del resto y nos presenta un buen estudio del diccionario o diccionarios que analiza; por otro lado, y esto es muy interesante, la lectura horizontal de todos los aspectos que se tratan en cada una de sus unidades. De esta manera el libro cobra un doble valor, pues no es solamente una excelente relación de artículos sobre diccionarios italoespañoles en una época cronológica determinada, sino que consigue, sin duda, convertirse en una historia de esta lexicografía bilingüe del último siglo, tal y como el mismo coordinador expone: «La de Textos fundamentales es una reseña de las obras más actuales y es una historia de la lexicografía italoespañola trazada por obras-capítulo, que puede conducir a capítulos de una historia de la metodología de la lexicografía italoespañola entre 1917 y 2007. (Págs. 17-18).

El libro se completa con dos capítulos de introducción en cada uno de los dos volúmenes. El primero a cargo del coordinador en el que explica la génesis y los presupuestos del trabajo, Introducción (págs. 7-26). El segundo, como presentación del segundo volumen dedicado a las obras de nuestro siglo, Estudio preliminar: Datos sobre el nuevo horizonte para la lengua española en Italia (Vol. 1, págs. 359-379) a cargo de C. Castillo Peña. Los volúmenes se cierran con dos listados de Bibliografía crítica (Vol. 1, págs. 339-351), (Vol. 2, págs. 781-794). Además, el segundo volumen contiene un listado bibliográfico de diccionarios (págs. 795806), un índice temático (págs. 807-833) especialmente valioso para la lectura y la consulta de aspectos particulares metalexicográficos, y un índice de nombres (págs. 834-840).

Por todo ello, Textos fundamentales de la lexicografía italoespañola (1917-2007) se convierte en un modelo muy válido e interesante de cómo se puede abordar un estudio lexicográfico amplio, y que resulte altamente productivo, y en una obra imprescindible tanto para 
el estudio de la historia de la lexicografía italoespañola en particular, como para cualquier especialista de la lexicografía en general.

Sin lugar a dudas, éste es un buen ejemplo de un amplio estudio lexicográfico que debería extenderse al resto de la historia de la lexicografía bilingüe italoespañola para que, en unos años, se pueda contar con su historia completa. 